\title{
ANALISIS KINERJA KEUANGAN DAN PENGARUHNYA TERHADAP PRICE EARNING RATIO (PER) PADA PT. HOLCIM INDONESIA TBK DI BURSA EFEK INDONESIA (BEI)
}

\author{
Andhika Napitupulu ${ }^{1)}$, Rina Dameria Napitupulu ${ }^{2)}$ \\ Sekolah Tinggi Ilmu Ekonomi Jayakarta \\ email: ${ }^{1)}$ andhika@stie.jayakarta.ac.id \\ ${ }^{2)}$ rina@stie.jayakarta.ac.id
}

\begin{abstract}
Abstrak
Penelitian ini dilakukan untuk mengetahui kinerjan keuangan secara keseluruhan dan seberapa besar pengaruhnya terhadap price earning ratio dan harga saham di Bursa Efek Indonesia. Objek yang digunakan dalam penelitian ini adalah PT. Holcim Indonesia Tbk, sedangkan jenis penelitian yang digunakan adalah penelitian lapangan dan kepustakaan. Untuk teknik pengumpulan data yang digunakan adalah teknik observasi dan dokumentasi. Teknik analisis data yang digunakan adalah rasio keuangan dan penilaian harga saham dan kesehatan saham PT. Holcim Indonesia Tbk untuk periode 2014- 2018.

Hasil penelitian ini menunjukkan bahwa kinerja keuangan berpengaruh terhadap earning per ratio, harga saham dan kesehatan saham. Dilihat dari aspek rasio keuangan menunjukkan PT. Holcim Indonesia Tbk dinilai illiquid pada tahun 2014 sampai dengan 2018 karena adanya penggunaan jangka pendek untuk keperluan pembiayaan aktiva tetap. Dari segi penilaian harga saham menunjukkan hasil menurun sejak tahun 2014-2018 yang sejalan dengan laba bersih yang diperoleh juga menurun. Sedangkan penilaian kesehatan saham secara keseluruhan menunjukkan posisi yang kurang sehat. Dari analisis ini keuangan terhadap harga saham dan price earning ratio menurun namun prospek usaha masih dinilai cukup baik. Dari hasil analisis perbandingan dengan perusahaan sejenis yaitu PT. Indocement Tunggal Prakarsa Tbk, bahwa harga saham dan kesehatan saham PT. Indocement lebih mahal dan lebih sehat dibandingkan dengan PT. Holcim Indonesia Tbk karena posisi keuangan yang lebih baik. Namun kedua perusahaan tersebut mempunyai prospek usaha yang masih cerah.
\end{abstract}

Kata Kunci : Kinerja keuangan, Harga Saham dan Price Earning Ratio (PER)

\section{PENDAHULUAN}

Meningkatnya persaingan saat ini menuntut setiap perusahaan untuk mampu menyesuaikan dengan keadaan yang terjadi dan menurut setiap perusahaan untuk dapat melakukan pengelolaan terhadap fungsi - fungsi yang ada dalam perusahaan sehingga dapat lebih unggul dalam persaingan yang dihadapi. Pada dasarnya perusahaan membutuhkan dana untuk menjalankan bisnisnya, apapun bentuk bidang usaha yang dijalankan oleh perusahaan tersebut dalam setiap kegiatan operasionalnya selalu memanfaatkan sumber daya dan sumber dana yang dimiliki secara optimal untuk memperoleh keuntungan dalam rangka meningkatkan pertumbuhan dan menjaga kelangsungan hidup usahanya dengan cara meningkatkan nilai perusahaan. Pemenuhan dana tersebut berasal dari sumber intern maupun sumber ekstern. 
Tingginya peningkatan konsumsi semen di dalam negeri, membuat beberapa produsen indonesia terus berlomba meningkatkan kapasitas produksinya. Salah satu produsen terbesar di Indonesia adalah PT. Holcim Indonesia Tbk. Ketatnya persaingan dalam industri produksi semen tidak membuat pergerakan bisnis PT. Holcim Indonesia Tbk menjadi stagnan. Sebaliknya PT. Holcim Indonesia Tbk terus mencari strategi dan peluang yang sesuai dengan kebutuhan dan permintaan pasar. Pada tahun 2014 kinerja keuangan perusahaan menghasilkan pertumbuhan penjualan sebanyak 19,8\% menjadi Rp 9,01 triliun, peningkatan laba $27 \%$ menjadi $\quad \mathrm{Rp} \mathrm{1,35}$ triliun, atau laba per lembar saham menjadi Rp 176 dari Rp 139 pada tahun 2011. PT. Holcim Indonesia Tbk tengah mengalami pertumbuhan seiring peningkatan pasar dengan pencapaian volume penjualan semen domestik $14,8 \%$ menjadi 8,59 juta ton.

Untuk dapat mendeteksi keadaan perusahaan apakah masih cukup likuid untuk beroperasi atau justru bermasalah, maka alat ukur yang utama digunakan adalah laporan keuangan perusahaan yang terdiri dari laporan laba rugi (profit and loss), neraca (balance sheet), dan kondisi arus kas (cash flow) perusahaan. Pemakai laporan keuangan meliputi investor, pemberi pinjaman, pelanggan, pemerintah serta lembaga - lembaganya, dan masyarakat. Laporan keuangan tersebut digunakan oleh mereka untuk memenuhi kebutuhan informasi yang berbeda.

Analisis faktor fundamental yang diperoleh dari kondisi intern perusahaan didasarkan pada laporan keuangan perusahaan yang dapat di analisis melalui analisis rasio - rasio keuangan dan ukuran - ukuran lainnya. Rasio keuangan dikelompokkan dalam lima jenis, yaitu :

1. Rasio Likuiditas, yaitu rasio yang digunakan untuk mengukur kemampuan perusahaan dalam membayar utang - utang jangka pendek.

2. Rasio Leverage, yaitu rasio yang digunakan untuk mengukur sampai seberapa jauh perusahaan dibiayai dengan utang.

3. Rasio Aktivitas, yaitu menyatakan kemampuan perusahaan dalam memanfaatkan harta yang dimilikinya.

4. Rasio Rentabilitas, yaitu rasio yang digunakan untuk mengukur efektivitas perusahaan dalam mendapatkan keuntungan.

5. Rasio Coverage, yaitu mengukur tingkat keamanan bank dalam pemberian kredit dengan tingkat kemampuan perusahaan membayar bunga pinjaman dan mengukur seberapa besar bagian dari laba bersih yang dibagi dalam bentuk deviden.

Selain itu juga dipergunakan instrumen untuk menganalisis penilaian harga saham dan kesehatan saham. Apakah harga saham di bursa murah atau mahal dan juga di nilai sehat atau buruk. Tingkat kemampuan atau kemajuan yang telah dicapai oleh perusahaan dalam pencapaian jumlah laba melalui analisis rasio laba bersih dibandingkan jumlah saham atau disebut earning per share merupakan alat untuk menghitung price earning ratio (PER). Apabila semakinrendah PER suatu saham semakin baik atau murah harganya karena memberikan hasil yang lebih tinggi, begitu juga sebaliknya bila PER suatu saham semakin tinggi maka semakin mahal harga per sahamnya.

\section{TINJAUAN PUSTAKA}

Kinerja keuangan merupakan usaha formal yang telah dilakukan oleh perusahaan yang dapat mengukur keberhasilan perusahaan dalam menghasilkan laba, sehingga dapat melihat prospek, pertumbuhan dan potensi perkembangan baik perusahaan dengan mengandalkan sumber daya yang ada. 
Pengertian laporan keuangan menurut Ikatan Akuntan Indonesia (2017, 1.3), adalah :

Laporan keuangan adalah suatu penyajian terstruktur dari posisi keuangan dan kinerja keuangan suatu entitas.

Laporan keuangan juga dijadikan sebagai salah satu alat pengambilan keputusan yang andal dan bermanfaat, sebuah laporan keuangan haruslah memiliki kandungan informasi yang bernilai tinggi bagi penggunanya. Informasi tersebut setidaknya harus memungkinkan investor dapat melakukan proses penilaian saham yang mencerminkan hubungan antara resiko dan hasil pengembalian yang sesuai dengan preferensi masing - masing jenis saham.

Kinerja keuangan sebuah perusahaan lebih banyak diukur berdasarkan rasio rasioa keuangan selama satu periode tertentu. Pengukuran berdasarkan rasio keuangan ini sangatlah bergantung pada metode yang digunakan dalam menyusun laporan keuangan perusahaan. Sehingga sering kali kinerja tersebut tidak mengalami peningkatan dan bahkan menurun.

Price Earning Ratio merupakan suatu rasio yang lazim dipakai untuk mengukur harga pasar setiap lembar saham biasa dengan laba per lembar saham. Menurut Moeljadi (2006: 75) Price Earning Ratio (PER) menunjukkan penilaian pasar saat ini terhadap sebuah saham, berdasarkan laba yang diperoleh tipa lembarnya; menunjukkan seberapa besar investor berminat untuk membayar tiap tsatuan moneter untuk mendapatkan yang diterimanya.

Rasio ini termasuk dalam klasifikasi rasio nilai pasar. PER melihat harga pasar saham relatif terhadap earning-nya. Perusahaan yang diharapkan mampu bertumbuh dengan tingkat pertumbuhan tinggi, biasanya mempunyai PER yang tinggi. Rasio harga laba (PER) juga merupakan ukuran untuk menentukan bagaimana pasar membeli nilai atau harga pada saham perushaan. Keinginan investor melakukan analisis saham melalui rasio rasio keuangan seperti PER dikarenakan adanya keinginan investor atau calon investor akan return (hasil) yang layak dari suatu investasi saham.

Saham merupakan salah satu jenis produk investasi di pasar modal. Sebagai produk investasi, saham memberikan manfaat atau keuntungan bagi para pemodal atau investor dengan tingkat pengembalian (return) yang menarik. Tujuan seseorang untuk melakukan investasi terhadap saham perusahaan go public pada umumnya semata - mata hanya mengharapkan keuntungan dari pembagian dividen dan capital gain.

Karakteristik saham perusahaan terbuka atau go public pada saham perusahaan tersebut ditransaksikan di bursa efek dengan karakteristik yaitu setiap saham yang diperdagangkan di pasar modal memiliki tiga jenis nilai yang melekat pada suatu saham perusahaan terbuka atau go public. Adapun nilai dari saham tersebut adalah nilai nominal, nilai wajar saham nilai pasar.

Faktor - faktor yang mempengaruhi naik turunya harga saham di bursa pada dasarnya disebabkan banyak faktor antara lain adalah perubahan performa perusahaan, kebijakan korporasi yang dilakukan perusahaan, kebijakan pemerintah, fluktuasi nilai mata uang, kondisi makro ekonomi dan politik keamanan, tingkat suku bunga perbankan dan rumor dan sentimen pasar.

Rasio keuangan merupakan alat analisis keuangan perusahaan untuk menilai kinerja suatu perusahaan berdasarkan perbandingan data keuangan yang terdapat pada laporan keuangan yaitu neraca, laporan laba rugi, dan aliran arus kas. Analisis rasio dapat digunakan untuk membimbing investor dan kreditor untuk membuat keputusan tentang pencapaian perusahaan pada masa yang akan datang. Metode penilaian dengan rasio keuangan yaitu rasio likuiditas menggunakan current 
ratio, cash ratio, quick ratio, dan net working capital. Rasio leverage menggunakan debt to equity ratio, long term leveragr, dan short term leverage. Rasio aktivitas menggunakan asst turnover, fixed asset turnove, account receivable turnover, collection period, inventory turnover dan account payable turnover. Rasio rentabilitas menggunakan gross profit margin, net profit margin, return on asset dan return on equity. Rasio coverage menggunakan ebit coverage ratio dan dividen pay out ratio.

Metode untuk penilaian harga saham adalah dengan menggunakan operating profit per share, earning per share, book value per share, price earning ratio dan price to book value. Kesehatan saham dilihat dengan menggunakan aktiva lancar net pada penjualan, laba usaha pada penjualan, laba usaha pada aktiva lancar, laba usaha pada aktiva usaha,total kewajiban pada laba usaha, return on equity, dan debt equity ratio.

\section{METODE PENELITIAN}

Penelitian yang digunakan adalah jenis deskriptif, yaitu penelitian yang bertujuan untuk membuat deskripsi secara sistematis, aktual, dan akurat mengenai fakta - fakta dan sifat - sifat dari populasi atau objek penelitian. Penelitian lapangan dengan menggunakan data primer dan langsung pada objek penelitiaan, yaitu berkaitan dengan kinerja keuangan PT. Holcim Indonesia Tbk. Penelitian kepustakaan dilakukan dengan cara membaca dan menelaah literatur - literatur yang berkaitan dengan perumusan masalah. Tujuan penelitian kepustakaan ini untuk mendapatkan data sekunder sebagai pemahaman teoritis tentang analisis kinerja keuangan dan pengaruhnya terhadap price earning ratio (PER) pada PT. Holcim Indonesia Tbk. Di Bursa Efek Indonesia.

Teknik pengumpulan data dengan teknik observasi yaitu teknik pengumpulan data yang dilakukan dengan pengamatan langsung terhadap laporan keuangannya. Dan dokumentasi dengan pengutipan dokumen berupa data historis perusahaan, studi literatur, laporan penelitian dan laporan keuangan yang diterbitkan perusahaan.

Populasi adalah wilayah generalisasi yang terdiri dari objek atau subjek yang mempunyai kuantitas dan karakteristik tertentu yang ditetapkan oleh peneliti untuk dipelajari dan kemudian ditarik kesimpulan menjadi suatu kesimpulan. populasi yang akan diteliti adalah price earning ratio pada PT. Holcim Indonesia Tbk dengan sampel sebagai elemen elemen atau anggota yang objeknya diambil untuk penelitian, diambil untuk periode tahun 2014-2018.

Teknik pengambilan sampel yang digunakan dalam penelitian ini adalah purposive sampling, yaitu pengambilan sampel berdasarkan tujuan dan pertimbangan tertentu. Data yang diambil adalah data keuangan dan non keuangan yang terbaru, data yang akurat selama lima tahun terakhir yaitu tahun 2014 sampai dengan tahun 2018 pada PT. Holcim Indonesia Tbk.

Teknik analisis data menggunakan adalah sebagai berikut :

1. Perhitungan Rasio Keuangan

a. Rasio Likuiditas :

1) Current Ratio

Aktiva Lancar

Kewajiban Lancar

2) Cash Ratio

(Kas + Surat Berharga)

-

Kewajiban Lancar

3) Quick Ratio

(Akt. Lancar--Persediaan)

Kewajiban Lancar


4) Net Working Capital

Aktiva Lancar--Kewajiban Lancar

b. Ratio Leverage :

1) Debt to Equity Ratio

Total Kewajiban

---o-------X 100\%

Modal Sendiri

2) Long Term Leverage

Utang Jk Panjang

---o----X 100\%

Modal Sendiri

3) Short Term Leverage

DER -- Long Term Leverage

c. Rasio Aktivitas :

1) Asset Turnover:

Penjualan Bersih

Total Aktiva

X 1Kali

2) Fixed Asset Turnover

Penjualan Bersih X 1Kali

Total Aktiva Tetap

3) Account Receivable Turnover

Penjualan Kredit

Piutang Usaha

4) Collection Period

360
ART

5) Inventory Turnover

360
HPP / Inventory

6) Account Payable Turnover

HPP
--------------- X 1Kali

d. Rasio Rentabilitas

1) Gross Profit Margin

\begin{tabular}{l} 
Laba Kotor \\
\hline Penjualan
\end{tabular}

2) Net Profit Margin

Laba Bersih
Penjualan

3) Return on Asset

Laba Bersih
Total Aktiva

4) Return on Equity Rasio

Laba Bersih

e. Rasio Coverage

1) Ebit Coverage Ratio

Laba sblm Bunga \& Pajak

$$
\text { Beban Bunga }
$$

2) Dividen Pay Out Ratio.

Dividen tunai
Laba Bersih sesdh Pajak

2. Perhitungan Penilaian Saham

a. Penilaian Harga Saham :

1) OPS

Laba Usaha 
Jumlah Saham

5) $\mathrm{ROE}$

2) EPS

$$
\begin{gathered}
\text { Laba Bersih } \\
- \text { Ekuitas }^{----}
\end{gathered}
$$

Laba Bersih

Jumlah Saham

6) DER

3) BVS

Total Kewajiban

Total Ekuitas

Ekuitas

Jumlah Saham

4) PER

Harga Saham

EPS

5) $\mathrm{PBV}$

Harga Saham

BVS

\section{PEMBAHASAN}

\section{Analisis Laporan Keuangan}

Atas dasar laporan keuangan perusahaan sejak tahun 2014 sampai dengan tahun 2018 dapat dianalisis rasio keuangan perusahaan, penilaian harga saham dan kesehatan saham PT. Holcim Indonesia Tbk.

Adapun data ditunjukkan dalam tabel dibawah ini :

b. Penilaian Kesehatan Saham :

1) ANPN

Aktiva Lancar

Pendapatan

2) LUPN

Laba Usaha

Pendapatan

3) LUAN

Laba Usaha

Aktiva Lancar Net

4) LUAH

Laba Usaha

Aktiva Usaha 


\begin{tabular}{|c|c|c|c|c|c|}
\hline & & Holcim Indonesia & Thk & & \\
\hline & Analisis & Perhitungan Rasio & Keuangan & & \\
\hline YETEPANGAN & & & TAHUN & & \\
\hline & 2014 & 2015 & 2016 & 2017 & \\
\hline Rasio Likuiditas: & & & & & \\
\hline Current Ratio & $59,52 \%$ & $65,67 \%$ & $45,94 \%$ & $54,36 \%$ & \\
\hline Cash Ratio & $5,64 \%$ & $15,93 \%$ & $6,10 \%$ & $10,30 \%$ & \\
\hline Quick Ratio & $43,00 \%$ & $51,86 \%$ & $35,46 \%$ & $38,00 \%$ & \\
\hline NWC & $\operatorname{Rp}(1.541 .356)$ & $\operatorname{Rp}(1.375 .667)$ & $\operatorname{Rp}(1.375 .667)$ & $\operatorname{Rp}(2.457 .792)$ & $R p$ \\
\hline Ratio Leverage: & & & & & \\
\hline DER & $100,41 \%$ & $105,58 \%$ & $145,18 \%$ & $172,70 \%$ & 18 \\
\hline Long Term Leverage & $56,05 \%$ & $58,16 \%$ & $79,29 \%$ & $97,88 \%$ & 10 \\
\hline Short Term Leverage & $44,00 \%$ & $47,00 \%$ & $66,00 \%$ & $75,00 \%$ & 8 \\
\hline Ratio Aktivitas: & & & & & \\
\hline Asset Turnover & 0,55 & 0,53 & 0,48 & 0,11 & \\
\hline Fixed Asset Turnover & 0,65 & 0,64 & 0,57 & 0,13 & \\
\hline Account Receivable Turnover & 9,16 & 8,39 & 9,24 & 1,84 & \\
\hline Collection Period (Days) & 39 & 43 & 39 & 196 & \\
\hline Perputaran Persediaan & 10,67 & 12,83 & 13,53 & 2,01 & \\
\hline Inventory Turnover (days) & 34 & 28 & 27 & 179 & \\
\hline Perputaran Utang Dagang & 6,29 & 6,56 & 6,71 & 1,30 & \\
\hline Perputaran Utang Dagang (hari) & 57 & 55 & 54 & 277 & \\
\hline Ratio Rentabilitas: & & & & & \\
\hline Gross Profit Margin & $29,27 \%$ & $23,16 \%$ & $20,41 \%$ & $18,02 \%$ & 1 \\
\hline Net Profit Margin & $6,96 \%$ & $1,90 \%$ & $-1,08 \%$ & $-5,40 \%$ & \\
\hline ROA & $3,84 \%$ & $1,01 \%$ & $-0,26 \%$ & $-0,59 \%$ & \\
\hline ROE & $7,69 \%$ & $2,07 \%$ & $-3,53 \%$ & $-1,62 \%$ & \\
\hline Ratio Coverage : & & & & & \\
\hline EBIT Coverage Ratio & $299,99 \%$ & $232,17 \%$ & $-152,85 \%$ & $340,64 \%$ & 5 \\
\hline Dividen Payout Ratio & $105,18 \%$ & $119,08 \%$ & $40,39 \%$ & $0,00 \%$ & \\
\hline
\end{tabular}

Dari hasil perhitungan diatas dapat di analisis sebagai berikut :

a. Rasio Likuiditas, rasio ini menunjukkan posisi yang illiquid pada tahun 2014 sampai dengan tahun 2018 menunjukkan hasil yang lebih besar minusnya, dengan demikian perusahaan tidak dapat memenuhi kewajiban jangka pendeknya dengan baik, hal ini dikarenakan adanya dana dari jangka pendek digunakan untuk pembiayaan aktiva tetap.

b. Rasio Leverage dan Solvabilitas, dari rasio ini tampak ada kenaikan dari tahun 2014 hingga tahun 2018, namun terlihat bahwa kewajiban perusahaan lebih kecil dibandingkan dengan equity nya. Sehingga leverage atau solvabilitas perusahaan dapat di nilai solvable.

c. Rasio Aktivitas, dari rasio ini terlihat bahwa manajemen dapat memanfaatkan setiap rupiah aktiva untuk menghasilkan penjualan. Begitu juga kemampuan perusahaan dalam membayar utangnyacukup baik yaitu tidak lebih dari 60 hari atau kurang lebih 2 bulan dan perusahaan bekerja efisien.

d. Rasio rentabilitas, dari rasio ini terlihat pada menurun, ini dikarenakan beban pokok penjualan dan beban operasi meningkat.

e. Rasio coverage, pada rasio ini terlihat tingkat kemampuan perusahaan untuk membayar bunga pinjaman cukup besar karena laba yang diperoleh (laba sebelum bunga dan pajak) lebih besar dari pada bunga yang harus dibayar. Sehingga apabila perusahaan diberikan pinjaman lagi maka masih bisa. Begitu juga dengan deviden tunai yang dibayarkan pada tahun 2014 sebesar $105,18 \%$ dan tahun 2015 sebesar $119,08 \%$. Sedangkan tahun 2018 menurun menjadi $0.00 \%$ dan sisanya $59,61 \%$ masuk laba ditahan

\section{Analisis Kinerja Keuangan dan Pengaruhnya terhadap Harga Saham dan PER}

Data keuangan dari hasil penelitian pada Bursa Efek Indonesia diawali dengan tabel penilaian harga saham PT. Holcim Indonesia Tbk yang diuraikan sebagai berikut :

\begin{tabular}{|c|c|c|c|c|c|}
\hline \multicolumn{6}{|c|}{ PT. Holdim Indonesia Tbk } \\
\hline \multicolumn{6}{|c|}{ Analisis Penilaian Harga Saham } \\
\hline \multirow{2}{*}{ KEERANGAN } & \multicolumn{5}{|c|}{ TAHUN } \\
\hline & 2014 & 2015 & 2016 & & \\
\hline Laba Usaha & Rp 1.206 .186 & Rp 909.489 & $\operatorname{Rp} \quad 205.872$ & Rp $\quad 22.896$ & Rp $\quad 106.912$ \\
\hline Laba Neto Tahun Berjalan & RP $\quad 659.867$ & Rp $\quad 175.127$ & $\operatorname{Rp} \quad(284.584)$ & $\operatorname{Rp} \quad(116.487)$ & ) $\operatorname{Rp} \quad(332.372)$ \\
\hline Laba Komprehensif Neto & Rp $\quad 568.820$ & Rp 144.983 & $\operatorname{Rp} \quad$ (274.318) & $\operatorname{Rp} \quad(116.948)$ & $\operatorname{Rp} \quad(343.745)$ \\
\hline Ekuitas Neto & Rp 8.581 .969 & Rp 8.449 .857 & Rp 8.060 .595 & Rp 7.196 .951 & Rp 6.853 .206 \\
\hline Laba Sebelum Pajak & Rp $\quad 928.746$ & Rp $\quad 350.418$ & $\operatorname{Rp} \quad(172.032)$ & Rp $\quad 23.630$ & Rp $\quad(109.077)$ \\
\hline Jumlah Saham/Lembar & 7.662 .900 .000 & 7.662 .900 .000 & 7.662 .900 .000 & 7.662 .900 .000 & 7.662 .900 .000 \\
\hline OPS (RP) & 15,74 & 11,87 & 2,69 & 0,30 & 1,40 \\
\hline EPS (RP) & 12,12 & 4,57 & $-2,24$ & 0,31 & 1,42 \\
\hline BVS (Rp) & 111,99 & 110,27 & 105,19 & 93,92 & 89,43 \\
\hline $\operatorname{PER}(\mathrm{RP})$ & 7,10 & 5,03 & 16,52 & $-48,39$ & 30,28 \\
\hline $\operatorname{PBV}(\operatorname{RP})$ & 0,77 & 0,21 & 0,35 & $\cdot 0,16$ & $-0,48$ \\
\hline Harga Saham / Lembar (Rp) & 86 & 23 & 37 & 15 & 43 \\
\hline
\end{tabular}

OPS digunakan untuk mengukur keberhasilan perusahaan dalam menghasilkan keuntungan melalui 
kegiatan usaha untuk setiap lembarnya. OPS PT. Holcim Indonesia Tbk mengalami penurunan karena adanya peningkatan beban pokok penjualan dan peningkatan beban usaha. EPS saham PT. Holcim Indonesia Tbk dari tahun 2014 sampai 2018 mengalami penurunan yang drastis, hal ini dikarenakan turunnya laba bersih perusahaan (rugi). BVS mengalami penurunan dikarenakan adanya penurunan ekuitas dari laba yang ditahan. PER saham PT. Holcim Indonesia Tbk pada tahun 2014 sebesar 7,10 kali, dan menurun pada tahun 2015 menjadi 5,03 kali, tetapi mengalami peningkatan yang signifikan pada tahun 2016 menjadi 16,52 kali. Hal ini sejalan dengan pendapatan dan laba yang diperoleh meningkatan. Nilai PBV PT. Holcim Indonesia Tbk pada tahun 2014 sebesar 0,77 kali, mengalami penurunan pada tahun 2015 menjadi 0,21 kali, dan mengalami penurunan lagi pada tahun 2018 menjadi -0,48 kali. Dari penilaian diatas dapat disimpulkan bahwa harga saham di Bursa Efek Indonesia mencerminkan keadaan keuangan perusahaan adalah laba bersih yang menurun.

Menilai kesehatan saham perusahaan diuraikan sebagai berikut :

\begin{tabular}{|c|c|c|c|c|c|}
\hline \multicolumn{6}{|c|}{ P. Holcim Indonesia Ib' } \\
\hline \multicolumn{6}{|c|}{ Analsis Peniliain Kesehatan Scham } \\
\hline & & & & & \\
\hline \multirow{2}{*}{ KEEERANGAN } & \multicolumn{5}{|c|}{ IAHUN } \\
\hline & 2014 & 2015 & 2016 & 2017 & 2018 \\
\hline Pendapatan Netto & Rp 2.775 .265 & Rp 2.139 .445 & Rp 1930.856 & Rp $\quad 388.943$ & Rp $\quad 291.269$ \\
\hline Laba Usaha & Rp 1.205 .186 & Rp $\quad 909.489$ & ho 205.872 & Alp 22.895 & $\operatorname{Rp} \quad 106.912$ \\
\hline Laba Bersih & $\begin{array}{ll}\text { Rp } \quad 659.867 \\
\end{array}$ & $\begin{array}{ll}\text { Ap } & 175.127 \\
\end{array}$ & Rp $\quad$ (284.584) & Ap (116.943) & \begin{tabular}{|ll} 
Ros & (343.745) \\
\end{tabular} \\
\hline Aktiva Lancar Netto & Rp 2.051 .619 & Rp 1.992 .749 & Rp 2.116.135 & Sp 2.372 .500 & Rg 2.646 .464 \\
\hline \begin{tabular}{|l} 
Altiva Tetap Nilai Buku \\
\end{tabular} & Rp 14.498.240 & Rp 14.427.080 & Rp 16.508.121 & Ap 15.999.771 & RP 15.774.085 \\
\hline Aktiva Usaha & Rp 14.428.998 & Rp 17.058.164 & Rp 19.048 .035 & Rp 18.926.782 & Rp 18.830 .995 \\
\hline Total Kevajiban & Rp 8.617 .335 & Rp 8.921 .018 & Rp 11.702.538 & Ap 12.429 .452 & Ro 12.674 .683 \\
\hline Kas dan Setara Kas & Rp $\quad 214.570$ & Ap $\quad 638.335$ & Alo $\quad 323.829$ & Rp $\quad 554.511$ & Rp $\quad 410.445$ \\
\hline Beban Usaha & Rp 1.709 .589 & Rp 1.815 .139 & Rp 1.555 .193 & Rip $\quad 356.004$ & Rp $\quad 360.033$ \\
\hline Total Ekuitas & Rp 8.581 .969 & Rp 8.449 .857 & Rp 8.060 .595 & Afp 7.196 .951 & ho 6.853 .205 \\
\hline ANPN & $73,90 \%$ & $93,14 \%$ & $109,60 \%$ & $609,99 \%$ & $908,60 \%$ \\
\hline WWPN & $43,45 \%$ & $42,51 \%$ & $10,66 \%$ & $5,89 \%$ & $39,19 \%$ \\
\hline WAN & $58,79 \%$ & $45,64 \%$ & $9,73 \%$ & $0,97 \%$ & $4,20 \%$ \\
\hline WAH & $8,36 \%$ & $5,33 \%$ & $1,08 \%$ & $0,12 \%$ & $0,59 \%$ \\
\hline KWL & 7,14 & 9,81 & 5,63 & 542,87 & 113,94 \\
\hline ROE & $7,69 \%$ & $2,07 \%$ & $-3,53 \%$ & $-1,62 \%$ & $-4,85 \%$ \\
\hline DER & $100,41 \%$ & $105,56 \%$ & $145,18 \%$ & $145,18 \%$ & $145,18 \%$ \\
\hline
\end{tabular}

Secara keseluruhan prosentase dari rasio ANPN mengalami kenaikan, artinya perputaran tingkat efisiensi penggunaan aktiva lancar PT. Holcim Indonesia Tbk kurang baik. Rasio LUPN mengalami penurunan, artinya kurang mempunyai kemampuan untuk menghasilkan laba. Rasio LUAN dan LUAH mengalami penurunan, menunjukkan bahwa perusahaan mempunyai kemampuan untuk menghasilkan laba berkurang karena kenaikan beban pokok penjualan dan beban usaha. Rasio KWLU menunjukkan perusahaan kurang mampu memenuhi kewajibannya, tahun 2014 sampai tahun 2018 masing-masing selama 7,14 tahun,9,3tahun dan 5,7 tahun. ROE perusahaan mengalami penurunan dan DER memenuhi kewajiban dari ekuitasnya, hasilnya kewajiban tersebut masih dapat tercover oleh ekuitas.

Kesimpulan dari data tersebut diatas secara keseluruhan, maka kesehtan saham perusahaan masih dinilai kurang sehat.

\section{Analisis Persaingan dengan Perusahaan Sejenis}




\begin{tabular}{|c|c|c|c|c|c|}
\hline \multicolumn{6}{|c|}{ PT. Holcim Indonesia Tbk } \\
\hline \multicolumn{6}{|c|}{ Analisis Perhitungan Rasio Keuangan } \\
\hline \multirow{2}{*}{ KETERANGAN } & \multicolumn{5}{|c|}{ TAHUN } \\
\hline & 2014 & 2015 & 2016 & 2017 & 201 \\
\hline \multicolumn{6}{|l|}{ Rasio Likuiditas: } \\
\hline Current Ratio & $59,52 \%$ & $65,67 \%$ & $45,94 \%$ & $54,36 \%$ & 5 \\
\hline Cash Ratio & $5,64 \%$ & $15,93 \%$ & $6,10 \%$ & $10,30 \%$ & \\
\hline Quick Ratio & $43,00 \%$ & $51,86 \%$ & $35,46 \%$ & $38,00 \%$ & 3 \\
\hline NWC & $\operatorname{Rp}(1.541 .356)$ & $\operatorname{Rp}(1.375 .667)$ & $\operatorname{Rp}(1.375 .667)$ & $\operatorname{Rp}(2.457 .792)$ & $\operatorname{Rp}(2.87$ \\
\hline \multicolumn{6}{|l|}{ Ratio Leverage: } \\
\hline DER & $100,41 \%$ & $105,58 \%$ & $145,18 \%$ & $172,70 \%$ & $184,9 !$ \\
\hline Long Term Leverage & $56,05 \%$ & $58,16 \%$ & $79,29 \%$ & $97,88 \%$ & $103,9 !$ \\
\hline Short Term Leverage & $44,00 \%$ & $47,00 \%$ & $66,00 \%$ & $75,00 \%$ & 81,00 \\
\hline \multicolumn{6}{|l|}{ Ratio Altivitas: } \\
\hline Asset Turnover & 0,55 & 0,53 & 0,48 & 0,11 & 0,11 \\
\hline Fixed Asset Turnover & 0,65 & 0,64 & 0,57 & 0,13 & 0,14 \\
\hline Account Receivable Turnover & 9,16 & 8,39 & 9,24 & 1,84 & 1,55 \\
\hline Collection Period (Days) & 39 & 43 & 39 & 196 & 226 \\
\hline Perputaran Persediaan & 10,67 & 12,83 & 13,53 & 2,01 & 1,99 \\
\hline Inventory Turnover (days) & 34 & 28 & 27 & 179 & 187 \\
\hline Perputaran Utang Dagang & 6,29 & 6,56 & 6,71 & 1,30 & 1,72 \\
\hline Perputaran Utang Dagang (hari) & 57 & 55 & 54 & 277 & 209 \\
\hline \multicolumn{6}{|l|}{ Ratio Rentabilitas: } \\
\hline Gross Profit Margin & $29,27 \%$ & $23,16 \%$ & $20,41 \%$ & $18,02 \%$ & 13,23 \\
\hline Net Profit Margin & $6,96 \%$ & $1,90 \%$ & $-1,08 \%$ & $-5,40 \%$ & 15,10 \\
\hline ROA & $3,84 \%$ & $1,01 \%$ & $-0,26 \%$ & $-0,59 \%$ & $-1,70$ \\
\hline ROE & $7,69 \%$ & $2,07 \%$ & $-3,53 \%$ & $-1,62 \%$ & $-4,85$ \\
\hline \multicolumn{6}{|l|}{ Ratio Coverage: } \\
\hline EBIT Coverage Ratio & $299,99 \%$ & $232,17 \%$ & $-152,85 \%$ & $340,64 \%$ & $503,2:$ \\
\hline Dividen Payout Ratio & $105,18 \%$ & $119,08 \%$ & $40,39 \%$ & $0,00 \%$ & 0,00 \\
\hline
\end{tabular}

PT. Holcim Indonesia Tbk

Analisis Penilaian Hargas Soham

\begin{tabular}{|c|c|c|c|c|c|}
\hline \multirow{2}{*}{ KEERANGAN } & \multicolumn{5}{|c|}{ TAHUN } \\
\hline & 2014 & 2015 & 2016 & & \\
\hline Laba Usaha & RP 1.206 .186 & Rp $\quad 909.489$ & RP $\quad 205.872$ & Rp 22.896 & $\operatorname{Rp} \quad 106$ \\
\hline Labo Neto Tahun Berjalan & Rp $\quad 659.867$ & Sp $\quad 175.127$ & $\begin{array}{ll}\operatorname{Rp} & \text { (284.584) } \\
\end{array}$ & $\operatorname{Re} \quad$ (116.487) & Sp $\quad 1332$ \\
\hline Laba Komprehensif́ Neto & Rp $\quad 568.820$ & Rp $\quad 144.983$ & Rp (274.318) & $\operatorname{Rp} \quad$ (116.948) & $\operatorname{Rp} \quad 1343$ \\
\hline Ekuitas Neto & Rp 8.581 .969 & Rp 8.449 .857 & Rp 8.060 .595 & $\operatorname{Rp} 7.196 .951$ & $\operatorname{Rp} 6.853$ \\
\hline Laba Sebelum Pajak & Rp $\quad 928.746$ & Bp $\quad 350.418$ & $\operatorname{Rp} \quad(172.032)$ & $\operatorname{Rp} \quad 23.630$ & Ap $\quad 109$ \\
\hline Jumlah Saham/lembar & 7.662 .900 .000 & 7.662.900.000 & 7.662.900.000 & 7.662.900.000 & 7.662 .900 \\
\hline $\operatorname{OPS}(\mathrm{RP})$ & 15,74 & 11,87 & 2,69 & 0,30 & 1,40 \\
\hline $\operatorname{EPS}\left(R_{p}\right)$ & 12,12 & 4,57 & $-2,24$ & 0,31 & 1,42 \\
\hline BVS (RP) & 111,99 & 110,27 & 105,19 & 93,92 & 89,43 \\
\hline PER (RP) & 7,10 & 5,03 & 16,52 & 48,39 & 30,28 \\
\hline $\operatorname{PBV}(\mathrm{RP})$ & 0,77 & 0,21 & $\cdot 0,35$ & 0,16 & $-0,48$ \\
\hline Harga Saham / Lembar (RP) & 86 & 23 & 37 & 15 & 43 \\
\hline
\end{tabular}

\begin{tabular}{|c|c|c|c|c|c|}
\hline \multicolumn{6}{|c|}{ PT. Holcim Indonesia Tbk } \\
\hline \multicolumn{6}{|c|}{ Andlsisis Penilaian Kesehatan Seham } \\
\hline & & & & & 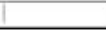 \\
\hline \multirow{2}{*}{ KETERANGAN } & \multicolumn{5}{|c|}{ IAHUN } \\
\hline & 2014 & 2015 & 2016 & 2017 & 2018 \\
\hline Pendapatan Netto & Rp 2.775 .265 & Rp 2.139 .445 & Rp 1.930 .856 & Ap $\quad 388.943$ & 291.269 \\
\hline Laba Usaha & Rp 1.205 .186 & Rp $\quad 909.489$ & Ap 205.872 & Ap $\quad 22.895$ & 106.912 \\
\hline Laba Bersih & Rp $\quad 659.867$ & Rp $\quad 175.127$ & Rp $\quad$ (284.584) & Ap (116.943) & Ap $\quad(343.745$ \\
\hline Aktiva Lancar Netto & Rp 2.051 .619 & Rp 1992.749 & Rp 2.116.135 & Ap 2.372 .500 & ho 2.645 .464 \\
\hline Aktiva Tetap Nilai Buku & Rp 14.493.240 & Rp 14.427.080 & Rp 15.608.121 & Ap 15.999.771 & R,p 15,774,085 \\
\hline Aktiva Usaha & Rp 14.428 .998 & Rp 17.058.164 & Rp 19.048 .035 & Ap 18.926.782 & h, 18.830 .995 \\
\hline Total Kewajiban & Rp 8.617 .335 & Rp 8.921 .018 & Rp 11.702.538 & Rp 12.429.452 & Rp 12.674 .683 \\
\hline Kas dan Setara Kas & Rp $\quad 214570$ & Rp $\quad 638.335$ & hlp $\quad 323.829$ & Rp $\quad 554.511$ & Rp $\quad 410.445$ \\
\hline Beban Usaha & Rp 1.709 .589 & Rp 1.815 .139 & Rp 1.655 .193 & Ap $\quad 356.004$ & Rp $\quad 360.033$ \\
\hline Total Ekuitas & Rp 8.581 .969 & Rp 8.449 .857 & Rp 8.060 .595 & Rp 7.196.951 & hop 6.853 .205 \\
\hline ANPN & $73,90 \%$ & $93,14 \%$ & $109,60 \%$ & $609,99 \%$ & $908,60 \%$ \\
\hline LWPN & $43,45 \%$ & $42,51 \%$ & $10,66 \%$ & $5,89 \%$ & $39,19 \%$ \\
\hline WAN & $58,79 \%$ & $45,64 \%$ & $9,73 \%$ & $0,97 \%$ & $4,20 \%$ \\
\hline WAH & $8,36 \%$ & $5,33 \%$ & $1,08 \%$ & $0,12 \%$ & $0,59 \%$ \\
\hline KWW & 7,14 & 9,81 & 5,63 & 542,87 & 113,94 \\
\hline ROE & $7,69 \%$ & $2,07 \%$ & $-3,53 \%$ & $-1,62 \%$ & $-4,85 \%$ \\
\hline DER & $100,41 \%$ & $105,58 \%$ & $145,18 \%$ & $145,18 \%$ & $145,18 \%$ \\
\hline
\end{tabular}

Penilaian harga saham dengan saingannya terlihat PT. Indocemet lebih sehat dibandingkan dengan PT. Holcim, karena KWLU kurang dari 1 tahun yang artinya hanya dalam setahun laba usaha dapat menutup semua kewajiban.

\section{SIMPULAN DAN SARAN}

\section{Simpulan}

Berdasarkan analisis data, maka hasil simpulan analisis kinerjaa keuangan dan pengaruhnya terhadap price earning ratio pada PT. Holcim Indonesia Tbk sebagai berikut :

1. Rasio likuiditas menunjukkan proses illiquid hasil yang lebih besar minusnya, dengan demikian perusahaan tidak dapat memenuhi kewajiban jangka pendeknya dengan baik, hal ini dikarenakan adanya dana dari jangka pendek digunakan untuk pembiayaan aktiva tetap.

2. Rasio Leverage dan Solvabilitas di nilai solvable.

3. Rasio Aktivitas, dari rasio ini terlihat bahwa manajemen dapat memanfaatkan setiap rupiah aktiva untuk menghasilkan penjualan.

4. Rasio rentabilitas, dari rasio ini terlihat pada menurun, ini dikarenakan beban 
pokok penjualan dan beban operasi meningkat.

5. Rasio coverage, pada rasio ini terlihat tingkat kemampuan perusahaan untuk membayar bunga pinjaman cukup besar.

6. Dari anlisis penilaian harga saham, terlihat harga saham menunjukkan hasil menurun, hal ini dikarenakan sejalan dengan laba bersih yang diperoleh juga menurun.

7. Analisis kesehatan sahamnya secara keseluruhanmenunjukan posisi yang sedikit kurang sehat.

8. Secara keseluruhan analisis kinerja keuangan terhadap PER menurun namun hal ini sejalan dengan menurunnya net profit margin dan prospek usaha masih dinilai cukup baik.

9. Dari analisis dengan perusahaan sejenis terlihat harga saham PT. Indocement lebih mahal dibandingkan PT. Holcim karena posisi keuangannya yang lebih baik, begitu juga dengan kesehatan saham nya lebih sehat PT. Indocement dari pada PT. Hplcim namun kedua perusahaan tersebut mempunyai prosek usaha yang cerah.

\section{Saran}

Dari hasil penelitian ini adalah PT. Holcim harus meningkatkan penjualannya dengan mencari daerah pemasaran yang baru dan melakukan promosi secara intensif, earning per share agar lebih diperbaiki dengan menekan harga pokok penjualan sehingga price earning ratio menjadi lebih murah, dan dalam pembelanjaan yang sehat disarankan sumber dana dari jangka pendek digunakan untuk aktiva lancar dan jangan digunakan untuk keperluan aktiva tetap agar modal kerja perusahaan meningkat.

\section{DAFTAR PUSTAKA}

Agus, D. Harjito \& Martono. 2011, Manajemen Keuangan. Edisi 2. Jakarta: Penerbit Ekonisia.

Ahmad Rodoni dan Othman Yong, 2013, Analisis Investasi dan Teori Portofolio, Murai Kencana, Jakarta.

Brigham, Eugene dan Joel F. Houston, 2011, Dasar-Dasar Manajemen Keuangan, Edisi ke-10, Salemba Empat, Jakarta.

Departemen Keuangan RI dan bapepam, Undang-Undang RI No. 8 Tahun1995, Tentang Pasar Modal.

Dermawan, Sjahrial. 2010. Manajemen Keuangan. Edisi 4. Jakarta: PT. Gramedia Pustaka Umum.

Eduardus, Tandelilin, 2010, Portofolio dan Investasi, Edisi ke-1, Kanisius, Yogyakarta.

Ikatan Akuntan Indonesia, 2018, Standar Akuntansi Keuangan, salemba Empat, Jakarta

Irham Fahmi, 2013, Pengantar Pasar Modal, Edisi ke-2, Alfabeta, Bandung.

Irham Fahmi, 2015, Manajemen Investasi, Edisi ke-2, Salemba Empat, Jakarta.

Jakarta Stock Exchange Statistic, Bursa Efek Indonesia 2014 - 2016.

Jogiyanto, Hartono, 2008, Teori Portofolio dan Analisis Investasi, BPFE, Yogyakarta. 
Mia Lasmi Wardiyah, 2017, Analisis Laporan Keuangan, Edisi 1, Pustaka Setia,Bandung.

Nor Hadi, 2013, Pasar Modal, Edisi ke-1, Graha Ilmu, Yogyakarta.

Rusdin, 2008, Pasar Modal, Alfabeta, Bandung.
Sunariyah, 2011, Pengantar Pengetahuan Pasar Modal, Edisi ke 6, UPP STIM YKPN, Yogyakarta.

Werner R. Murhadi, 2009, Analisis Saham Pendekatan Fundamental, Indeks, Jakarta.

www.bapem.co.id

$\underline{\text { www.idx.co.id }}$ 